\title{
The Impact of Job Satisfaction and Organization Commitment on Organizational Citizenship Behavior of Public School Teachers in Anuradhapura District, Sri Lanka
}

\author{
P.T.G.C.I. Jayawardena ${ }^{1}$, Dr. U.W.M.R. Sampath Kappagoda ${ }^{2 *}$ \\ ${ }^{1}$ Department of Business Management, Faculty of Management Studies, Rajarata University of Sri Lanka, \\ Mihintale, Sri Lanka \\ ${ }^{2}$ Senior Lecturer, Faculty of Management Studies, Rajarrata University of Si Lanka, Mihintale, Sri Lanka \\ *Corresponding Author: U.W.M.R. Sampath Kappagoda, Senior Lecturer, Faculty of Management \\ Studies, Rajarrata University of Si Lanka, Mihintale.
}

\begin{abstract}
Organization Citizenship Behavior $(O C B)$ is one of the critical factors that decide the organization success and it is shaped by many factors. Among them job satisfaction and organization commitment play major role in deciding $O C B$. It can be observed many examples that reflect poor OCB of teachers in Sri Lankan education sector in recent past. Therefore, this study aims to examine the impact of job satisfaction and organization commitment on OCB among public school teachers. This research is a basic research and a quantitative study. The Advance Level Science stream teachers of public schools in Anuradhapura district was the population of this study. A sample of 100 teachers was selected through proportionate stratified sampling technique using a questionnaire. Univariate, bivariate and multivariate methods of data analysis were used in the data analysis such as central tendency, measures of dispersion, Multiple Linear Regression, Correlation Coefficient. The results revealed that there was a moderate positive relationship between job satisfaction and $O C B$ and $a$ weak positive relationship between organization commitment and OCB. These findings lead to important managerial and policy implications.
\end{abstract}

Key words: Job Satisfaction, Organizational Citizenship Behavior, Organizational Commitment, Teachers

\section{INTRODUCTION}

A teacher is a person who plays a significant role in the school and considered as the "second parent" of a student's life. Teacher is the only person who is capable of imparting knowledge and shaping the youths to the wider scope of knowledge. Teachers are capable of living and molding the youths such that teachers' power is paramount as they determine the fate of the society. Teachers are at the core of achieving the Sustainable Development Goals (SDGs); in particular, teachers are central to meeting goals and are extremely important character in the society, that moulds the lives of the next generation, who will become the leaders in the country in future. According to Zeinabadia\&Salehib (2011), if a teacher is well educated and committed to their job then only the success of student will be decided and it will responsible citizen and a leader to the country.

In previous studies found that employee behavior is the most important factor of the organizational success. Among those behaviors, Organizational Citizenship Behavior (OCB) has major contribution on the success of any organization. Because organization can achieve their objectives without bearing any additional cost. According to Organ (1988), OCB represents "Individual behavior that is discretionary, directly, not directly or explicitly recognized by the formal reward systems, and in the aggregate promotes the efficient and effective functioning of the organization". When look into the context of teachers, they possess a specific type of behavior towards the achievement of students. And most of those behaviors are voluntary and not forced by anybody. Some of such actions are: Arrive at work early and leave late, avoid prolonged or unnecessary breaks, be punctual for meetings, classes and lessons, complete syllabuses before they are due, conserve school resources, make constructive suggestions and feedbacks, assume added responsibilities to help the students in need (Ehtiyar, Alan, \&Omuris, 2010). 
But according to the information of current teacher's behaviors, there is a problem that present teachers have real OCB. Because, according to the news article on Lankadeepa newspaper (29th May 2014), Education minister in Uva Province said that due to school teachers engaging in private tuition classes, entire school activities had dimidiated. Further, Lankadeepa newspaper (03rd September 2018) reported that grade one students sent back to homes due to the class teacher's absence. In reviewing the ideas of the current students, their opinion says that teachers are engaging in doing private classes, so that their responsibilities at school are not met appropriately as well as teachers treats differently for the students who do not participate to their classes. According to that information there is a problem that current teachers got real OCB. Therefore, it is very important to investigate the influencing factors on OCB. Among various antecedents, Job Satisfaction and Organizational Commitment are the most influencing factors on OCB (Zeinabadia\&Salehib ,2011). Therefore, the main purpose of this research is to investigate the impact of Job Satisfaction and Organizational Commitmenton OCBof Public School Teachers in Anuradhapura District in Sri Lanka. Therefore, the current study has two goals: 1) to investigate the impact of Job Satisfaction on OCB, and 2) to investigate the impact of Organization Commitment on OCB.

\section{LITERATURE REVIEW}

\subsection{Organizational Citizenship Behavior}

OCB is very important to every organization. Organization can achieve their goals and objective without bearing any additional cost and further it is help to enhance the organization social machinery of the organization, reduce friction, and increase efficiency (Rangriz, 2012).Organ (1988) defined the organizational citizenship behavior as "The voluntary individual action which is not defined clearly in the formal reward and punishment system of the organization but supporting the effectiveness and efficiency of the organization as a whole".Similarly,Lee, Kim, and Kim (2013)defined OCB as extra arbitrary behaviors by employees, which are not formally rewarded by the organization because of those behaviors are beyond the employee's duties, although an employee does not practice those behaviors organization cannot be punished for that employee.

Moreover, Smith, Organ, and Near (1983) identifiedOCB as discretionary behavior that goes beyond one's official role and is intended to help other people in the organization or to slow conscientiousness and support toward the organization. There are lots of factors that affect to OCB. Among various antecedents, job satisfaction and organizational commitment appear to be good predictor of OCB (Organ and Ryan, 1995; Pitaloka\& Sofia, 2014; Zeinabadia\& Salehib, 2011; Liu, 2009).

\subsection{Job Satisfaction and Organizational Citizenship Behavior}

Job satisfaction is a very important attribute, which is concerned by every organization. Different people have given different views regarding job satisfaction through various studies. Armstrong (2006)defined the term of job satisfaction refers to the attributed and feelings people have about their work. Positive and favorable attitudes towards the job indicate job satisfaction. General satisfaction of life highly depends on Job satisfaction which gives energy for the employees to perform well and retain in their jobs. Further Parmar (2012) defined it as "job satisfaction is any combination of psychological, physiological and environmental circumstances that cause a person truthfully to say I am satisfied with my job".

There is considerable support for the relationship between job satisfaction and OCB (Bateman \& Organ, 1983; Organ, 1988; Williams \& Anderson, 1991); Schappe, 1998; Ngunia, Sleegers, \&Denessen, 2006). According to Zeinabadia and Salehib (2011), employees who are more satisfied with their jobs demonstrate more OCB. The similar result found in the study carried by the PavalacheIlie (2014). Moreover, the findings of the study conducted by Chiboiwa, Chipunza, and Samuel (2011) showed there is the strong and positive correlation between job satisfaction and OCB. Asari, Abdullah and Wibowo (2018) carried out a study on the effect of personality, organizational climate and job satisfaction on teacher'sOCB at public vocational high school in DKI Jakarta Province using a sample of 212 teachers, and they found a direct positive effect of job satisfaction on OCB. Hemakumara, Khatibi\&Johar, (2018) found a significant and positive relationship between job satisfaction and OCB with the sample of 168 administrative officers in state universities in Sri Lanka. 
Similarly, Ramadhan \&Yenni (2018) found positive relationship between job satisfaction and OCB.Hence the following hypothesis issuggested:

H1: There is a positive relationship between Job satisfaction and organizational citizenship behavior.

\subsection{Organization Commitment and Organizational Citizenship Behavior}

Organizational Commitment is one of the most interested area among the researchers within last decade because it has higher influence to the Organizational performance.

Organizational commitment is the behavior of an individual articulated in correspondence to his/her dependence on a precise organization (Meyer and Allen (1997). Pitaloka and Sofia (2014) conducted a study using 162 respondents of internal auditors to identify the effect of work environment, job satisfaction, organization commitment on organizational citizenship behavior of internal auditors and the result showed that job satisfaction and organizational commitment significantly affect OCB of internal auditors.According to the research conducted by Zeinabadia and Salehib (2011) using a sample of teachers found that teachers who are satisfied from their job, are more committed to school and subsequently are more engaged in citizenship behaviors. Zayas-Ortiz, Rosario, Marquez \&Gruñeiro (2015) found a positive relationship between organizational commitment and OCB with the sample of 154 private banks employees whist, Ibrahim \&Aslinda (2013) found similar result through their sample of employees at government owned corporation companies.Based on the previous evidence following hypothesis is suggested:

H2: There is a positive relationship between Organization commitment and organizational citizenship behavior.

\section{RESEARCH METHODOLOGY}

\subsection{The Research Design}

In this study, the researcher examines the impact of job satisfaction and organizationalcommitment of teachers onOCB. Therefore, the purpose of this study is hypothesis testing that seeks to explore the relationships among variables. The current study employed a correlational study in order to explore the relationship between job satisfaction, organizational commitment of the respondents (independent variables) and their Organizational Citizenship Behavior (dependent variable). This field study is conducted in natural environment in public school sector under minimal interference with noncontrived settings. This study is a cross sectional study. For this purpose, data were collected from public school teachers in Anuradhapura District in Sri Lanka. Therefore, the unit of analysis of this research is "individual".

\subsection{Population and Sample}

The sample of this study was drawn from the population comprised of all the public schools' teachers who are working under the category of $1 \mathrm{AB}$ - Schools having Advance Level Science stream classesin Anuradhapura educational zone in Sri Lanka. The sample of 100 teachers from category $1 \mathrm{AB}$ was selected using proportional stratified sampling technique.

In terms of demographics, there were more female teachers $(73 \%)$ than male teachers. $86 \%$ teachers were married. The majority of teachers (51\%) were less than 45 years of age. $42 \%$ teachers earned a university degree.The majority of teachers $(33 \%)$ had less than 10 years of work experience.

\subsection{Measures}

Three variables in the research: Job satisfaction, organizational commitment and OCBwere measured through standard questionnaires with five -point Likert scales, ranging from 1(strongly disagree) to 5(strongly agree). The level of job satisfaction, organizational commitment and OCB of teachers were evaluated by themselves. OCB was measured using a standard questionnaire consisting 15 statements. Job satisfaction was measured using 15 statements and organizational commitment was measured by an instrument consisting 10 statements.

\subsection{Validity and Reliability}

The content validity of these instruments was secured by including an adequate number of questions for each dimension of the variables. The results of Cronbach Coefficient Alpha (Table 01) which 
The Impact of Job Satisfaction and Organization Commitment on Organizational Citizenship Behavior of Public School Teachers in Anuradhapura District, Sri Lanka

suggested each item is correlated with other item across the entire sample and the internal consistencyreliability is satisfactory.

Table1. Cronbach Coefficient Alpha Value for variables

\begin{tabular}{|l|l|l|}
\hline Variables & Cronbach Coefficient Alpha & Number of Items \\
\hline Job satisfaction & 0.810 & 15 \\
\hline Organizational Commitment & 0.715 & 10 \\
\hline OCB & 0.830 & 15 \\
\hline
\end{tabular}

\subsection{Data Analysis}

The data analysis was included univariate, bivariate and multivariate analyses. The data was processed using the Statistical Package for the Social Sciences; version 20.0 () to analyze the data collected.

Table2. Descriptive statistics for variables

\begin{tabular}{|l|l|l|}
\hline Variable & Mean & Std. Deviation \\
\hline Job Satisfaction & 3.1520 & 0.42641 \\
\hline Organization Commitment & 3.0730 & 0.49845 \\
\hline OCB & 2.6733 & 0.45900 \\
\hline
\end{tabular}

According to the Table 2, Job satisfaction and Organizational Commitment of the teachers are in moderate level, but OCB is in the low level in the teachers of Anuradhapura District in Sri Lanka.

Table3. Correlations between variables

\begin{tabular}{|l|l|}
\hline & OCB \\
\hline Job Satisfaction & $0.650^{* *}$ \\
\hline Organization Commitment & $0.167^{*}$ \\
\hline$* *$. Correlation is significant at the 0.01 level (1-tailed). \\
$*$. Correlation is significant at the 0.05 level (1-tailed). \\
\hline
\end{tabular}

Table4. The results of regression analysis

\begin{tabular}{|l|l|l|l|l|l|}
\hline adjusted $\mathrm{R}^{2}=0.416$ & \multicolumn{2}{|c|}{$\mathrm{F}=36.321$} & \multicolumn{2}{l}{ Sig $=0.000$} \\
\cline { 1 - 4 } & Unstandardized Coefficients & Standardized Coefficients & \multirow{3}{*}{ S } \\
\cline { 2 - 4 } & $\mathrm{B}$ & Std. Error & Beta & & \\
\hline (Constant) & .281 & .320 & & .879 & .382 \\
\hline Job satisfaction & .688 & .083 & .639 & 8.239 & .000 \\
\hline Organization Commitment & .073 & .071 & .079 & 1.025 & .308 \\
\hline
\end{tabular}

According to the results of the Pearson's Correlation Coefficient as shown in the Table 3, the correlation between Job Satisfaction and $\mathrm{OCB}(\mathrm{r}=0.65, \mathrm{P}<0.01)$ was significant and positive. The Correlation between Organization Commitment and OCB $(r=0.167, \mathrm{P}<0.05)$ was also significant with weak positive.

However, according to the result of the regression analysis which is reported in table 04. The job satisfaction has positive impact on OCB $(\beta=.688, p<0.00)$ but organizational commitment has no any impact on OCB $(\beta=.073, \mathrm{p}>0.00)$. And also, job satisfaction and organizational commitment explain $41.6 \%$ of the variance in OCB. Thus, $\mathrm{H} 1$ was supported and $\mathrm{H} 2$ was not supported.

\section{Discussion and Conclusion}

The objective of this study was to identify the impact of job satisfaction and organizational commitment on public school teachers' OCB. According to the findings, the job satisfaction has positively and significantly correlated with OCB.This finding is consistent with the results obtained by Hemakumara, Khatibi\&Johar, (2018). However, organizational commitment has not significant impact on OCB. These findings are useful in highlighting the need for the decision makers in education sector to develop appropriate strategies and human resource practices in order to improve its high employee Organizational Citizenship Behavior in the future.

\section{REFERENCES}

[1] Armstrong, M. (2006). A Hand Book of Human Resource Management Practice 10th Edition. London: London: kogan page publishing. 
[2] Asari, Abdullah, T., \& Wibowo. (2018). The Effect of Personality, Organizational Climate and Job Satisfaction on Teachers Organizational Citizenship Behavior at Public Vocational High School in DKI Jakarta Province. International Journal of Scientific Research and Management, 06(4), 191-197.

[3] Bateman, S. T., \& Organ, D. W. (1983). Job Satisfaction and the Good Soldier: The Relationship Between Affect and Employee "Citizenship". Academy of Management Journal, 26 (4), 587-595.

[4] Chiboiwa, M. W., Chipunza, C., \& Samuel, M. O. (2011). Evaluation of Job Satisfaction And Organizational Citizenship Behavior: Case study of selected organizations in Zimbabwe. African Journal of Business Management, 5(7), 2910-2918.

[5] Hemakumara, M.G.G., Khatibi, A.A., Johar, D. Job (2018). Satisfaction and Organizational Citizenship Behavior among the Administrative Staff of State Universities in Sri Lanka, 7 (8), 40-44

[6] Ehtiyar, V. R., Alan, A. A., \& Omuris, E. (2010). The Role of Organizational Citizenship Behavior. Tourism and Hospitality Management,16(1), 47-61.

[7] Ibrahim, M.A., \&Aslinda, A. (2013). Relationship between Organizational Commitment and Organizational Citizenship Behavior (OCB) at Government-Owned Corporation Companies, Journal of Public Administration and Governance, 3 (3), 35-42.

[8] Lee, U., Kim, H., \& Kim, Y. (2013). Determinants of Organizational Citizenship Behavior and Its Outcomes. Global Business and Management Research: An International Journal, 5(1), 54-65.

[9] Liu, Y. (2009). Perceived Organizational Support and Expatriate Organizational Citizenship Behavior : The Mediating Role of Affective Commitment towards the Parent Company. Personnel Review, 38 (3), 307-319.

[10] Meyer, J. P., \& Allen, N. J. (1997). Commitment in the Workplace: Theory, Research, and Application. United States of America: Sage Publications.

[11] Monoshree, M. (2012). Personal Characteristics and Job Satisfaction as Predictor of Organizational Commitment: an Empirical Investigation. South Asian Journal of Management, 100 -119.

[12] Ngunia, S., Sleegers, P., \& Denessen, E. (2006). Transformational and Transactional Leadership Effects on Teachers' Job Satisfaction, Organizational Commitment, and Organizational Citizenship Behavior in Primary Schools: The Tanzanian case. School Effectiveness and Personnel Psychology, 48, 775-802.

[13] Organ, D. W. (1988). Organizational Citizenship Behavior: The Good Solider Syndrome. Lexington: MA: Lexington Books.

[14] Organ, D. W., \& Rayan, K. (1995). A Meta-analytic Review of Attitudinal and Dispositional Predictors of Organizational Citizenship Behavior. Personnel Psychology, 48(4), 775-802.

[15] Parmar, D. N. (2012). The review of job satisfaction. International multidisciplinary e-journal, 24 - 39.

[16] Pavalache-Ilie, M. (2014). Organizational citizenship behaviour, work satisfaction and employees' personality. Procedia - Social and Behavioral Sciences, 127, 489 - 493.

[17] Pitaloka, E., \& Sofia, I. P. (2014). The Affect of Work Environment, Job Satisfaction, Organaization Commitment on OCB of Internal Auditors. International Journal of Business, Economics and Law, 5(2), 10-18.

[18] Ramadhan, N., \&Yenni (2018). Effect of Employee Job Satisfaction on OrganizationaCitizenship Behavior at Assessment Center Indonesia, 7 (4.34), 253-256.

[19] Rangriz, H. (2012). Relationship between Organizational Justice and Organizational Citizenship Behavior in Iran. International Journal of Asian Social Science, 2(5), 587-595.

[20] Schappe, P. (1998). The influence of job satisfaction, organizational commitment, and fairness perceptions on organizational citizenship behavior . The Journal of Psychology,132(3), 277-290.

[21] Schaubroeck, J., \& Ganster, D. C. (1991). Beyond the call to duty: A field study of extra-role behavior in voluntary organizations. Human Relations, 44, 569-582.

[22] Singh, J. P., \& Chand, P. K. (2018). A Review Analysis of Job Satisfaction as an Antecedent of Organization Citizenship Behavior. International Journal of Research and Analytical Reviwes, 5(3), 719726.

[23] Smith, C. A., Organ, W. D., \& Near, J. P. (1983). Organizational Citizenship Behavior: Its Nature and Antecedents. Journal of Applied Psychology, 68 (4), 653-663.

[24] Williams, L. J., \& Anderson, S. E. (1991). Job Satisfaction and Organizational Commitment as Predictors of Organizational Citizenship and In-Role Behaviors. Journal of Management, 17(3), 601-617.

[25] Zayas-Ortiz,Rosario, E., Marquez, E., \&Gruñeiro, P.C. (2015). Relationship between organizational commitments and organizational citizenship behaviour in a sample of private banking employees, International Journal of Sociology and Social Policy, 35 (1/2), 91-106. 
The Impact of Job Satisfaction and Organization Commitment on Organizational Citizenship Behavior of Public School Teachers in Anuradhapura District, Sri Lanka

[26] Zeinabadia, H., \& Salehib, K. (2011). Role of procedural justice, trust, job satisfaction, and organizationalcommitment in Organizational Citizenship Behavior (OCB) ofteachers: Proposing a modified social exchange model. Procedia - Social and Behavioral Sciences, 29, 1472 - 1481.

Citation: P.T.G.C.I. Jayawardena, Dr. U.W.M.R. Sampath Kappagoda. "The Impact of Job Satisfaction and Organization Commitment on Organizational Citizenship Behavior of Public School Teachers in Anuradhapura District, Sri Lanka" International Journal of Humanities Social Sciences and Education (IJHSSE), vol 7, no. 9, 2020, pp. 69-74. doi: https://doi.org/10.20431/2349-0381.0709006.

Copyright: (c) 2020 Authors. This is an open-access article distributed under the terms of the Creative Commons Attribution License, which permits unrestricted use, distribution, and reproduction in any medium, provided the original author and source are credited. 